\title{
Novel BRAF alteration in desmoplastic infantile ganglioglioma with response to targeted therapy
}

\author{
Melissa M. Blessing ${ }^{1}$, Patrick R. Blackburn', Jessica R. Balcom', Chandra Krishnan ${ }^{3}$, Virginia L. Harrod ${ }^{4}$, \\ Michael T. Zimmermann ${ }^{5}$, Emily G. Barr Fritcher ${ }^{1}$, Christopher D. Zysk ${ }^{1}$, Rory A. Jackson ${ }^{1}$, Asha A. Nair ${ }^{2}$, \\ Robert B. Jenkins', Kevin C. Halling ${ }^{1}$, Benjamin R. Kipp ${ }^{1}$ and Cristiane M. Ida ${ }^{1 *}$
}

Keywords: BRAF, DIG, MAPK, Targeted therapy

Desmoplastic infantile ganglioglioma (DIG) and desmoplastic infantile astrocytoma (DIA) are rare, low-grade neuroepithelial neoplasms [1]. BRAF alterations, primarily the V600E mutation and rarely V600D and FXR1-BRAF fusion [3-5, 8, 10, 12], have been described for DIG/DIA. Although gross total resection is typically curative, tumor location may prevent complete tumor excision. Additionally, tumor recurrence, progression, and rarely leptomeningeal dissemination have been reported [2, 9], underscoring the need for adjuvant treatment.

With comprehensive molecular analysis, we identified a novel BRAF alteration in a DIG in a 3-month-old female patient who had seizures, apnea, and a right postcontrast enhancing temporal solid multicystic mass (Fig. 1a). Three months after near-total tumor resection, progressive brainstem leptomeningeal spread (Fig. 1b) prompted a second operation (near-total completion). The tumors from both resections were histologically similar: A prominent desmoplastic stroma had astrocytic, neoplastic neuronal, and poorly differentiated neuroepithelial tumor cell components (Fig. 2). Mitotic activity (up to 6/10 high-power fields) was limited to the poorly differentiated neuroepithelial component.
Neither necrosis nor microvascular proliferation was observed.

Comprehensive molecular tumor profiling was performed with a 150-gene DNA and an 81-gene RNA neurooncology next-generation sequencing panel (Additional file 1: Methods). A BRAF indel involving codons 600-604 (c.1799_1810delinsACCAAACTGATG; p.V600_W604delinsDQTDG) at low variant allelic frequency (approximately 15\%) was the only clinically relevant alteration identified (Additional file 2: Figure S1). This alteration was confirmed with Sanger sequencing (Additional file 3: Figure S2), and mRNA expression was demonstrated with RNA sequencing (Additional file 4: Figure S3). In silico protein modeling (Additional file 1: Methods) with wild-type, pS602, and V600E comparators showed that the novel $B R A F$ indel had the greatest positional change compared with wild-type, which was consistent with stabilization of the kinase-active conformation (Fig. 3 and Additional file 5: Figure S4).

Postoperatively, vincristine and carboplatin chemotherapy was initiated upon disease progression. Despite treatment, the leptomeningeal lesions continued to progress (Fig. 1c), and treatment was switched to BRAF-MEK inhibitors (dabrafenib and trametinib)

\footnotetext{
* Correspondence: ida.cristiane@mayo.edu

Portions of this manuscript were presented at the 94th Annual Meeting of the American Association of Neuropathologists, Inc, Louisville, Kentucky, June 7-10, 2018, and published in abstract form: J Neuropathol Exp Neurol. 2018 June;77(6):500.

'Department of Laboratory Medicine and Pathology, Mayo Clinic, 200 First St SW, Rochester, MN 55905, USA

Full list of author information is available at the end of the article
} 


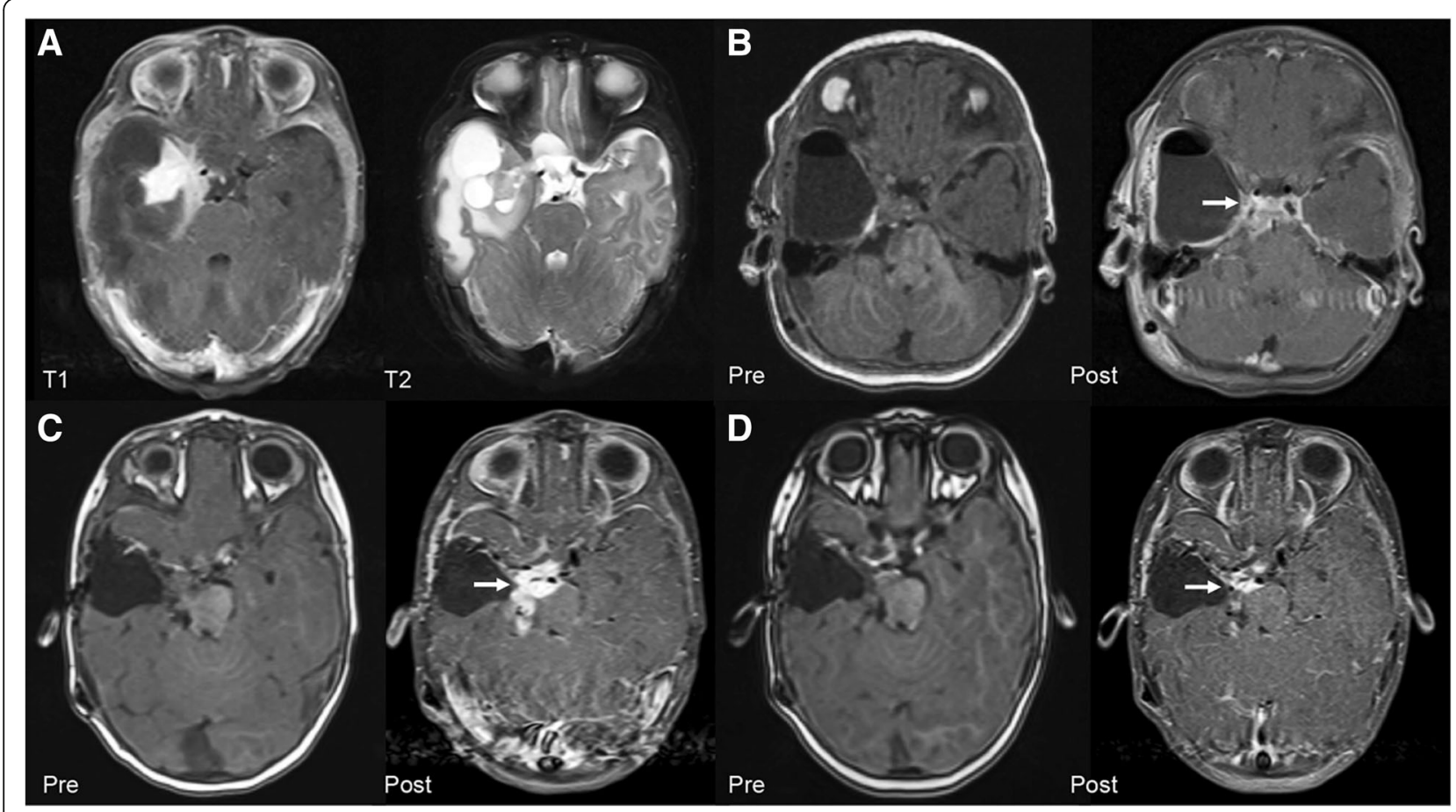

Fig. 1 Radiologic findings. a (T1-Weighted Postcontrast and T2-Weighted Axial Magnetic Resonance Imaging), Large right inferomedial temporal solid-multicystic mass with a postcontrast enhancing component. b (T1-Weighted Pre and Postcontrast Axial Magnetic Resonance Imaging), Three-month postoperative leptomeningeal spread involving the upper brainstem. c (T1-Weighted Pre and Postcontrast Axial Magnetic Resonance Imaging), Eight-month postoperative progression of leptomeningeal involvement despite standard chemotherapy. d (T1-Weighted Pre and Postcontrast Axial Magnetic Resonance Imaging), Fourteen-month postoperative decrease in residual tumor after 6 months of BRAF-MEK inhibitor therapy

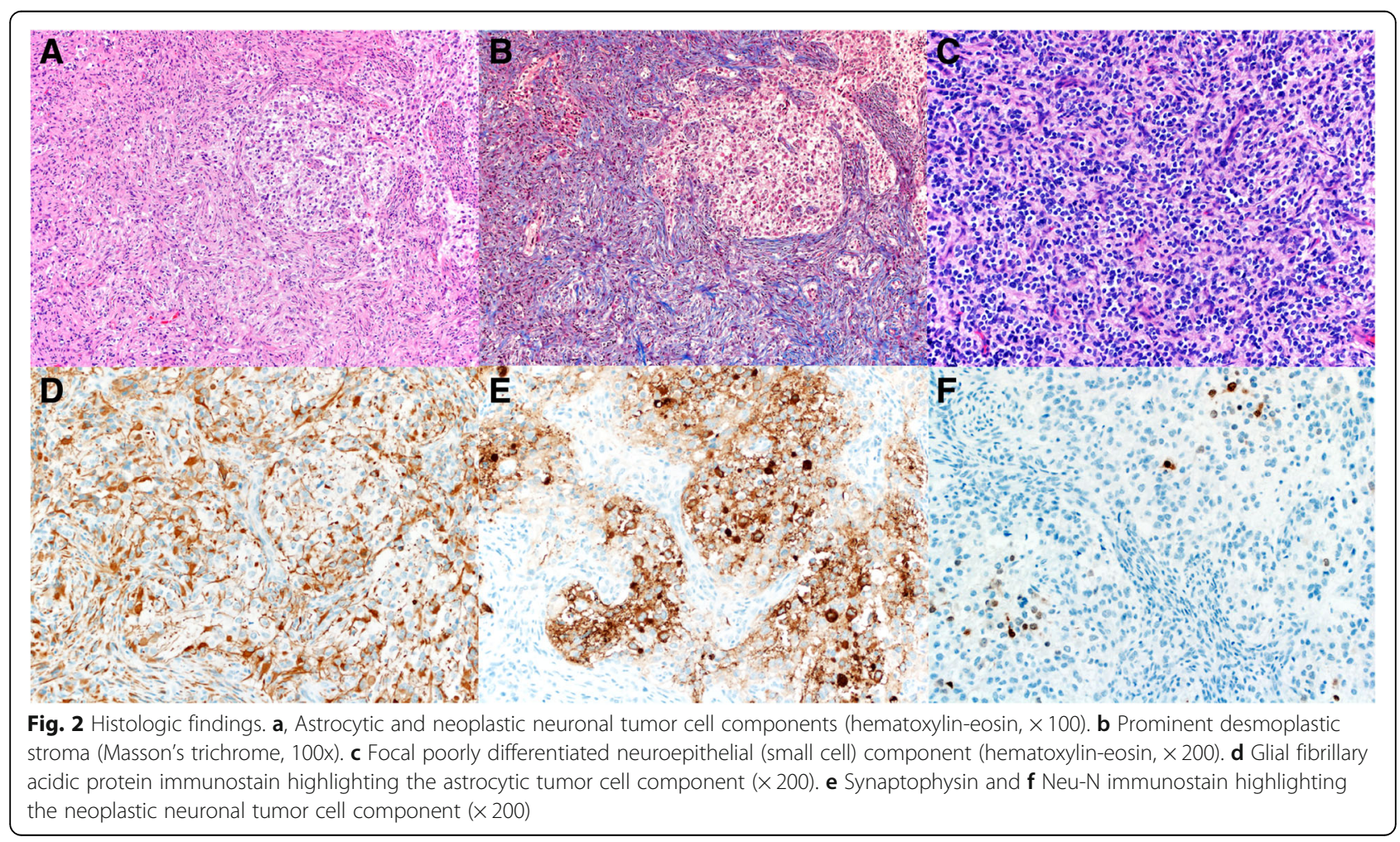



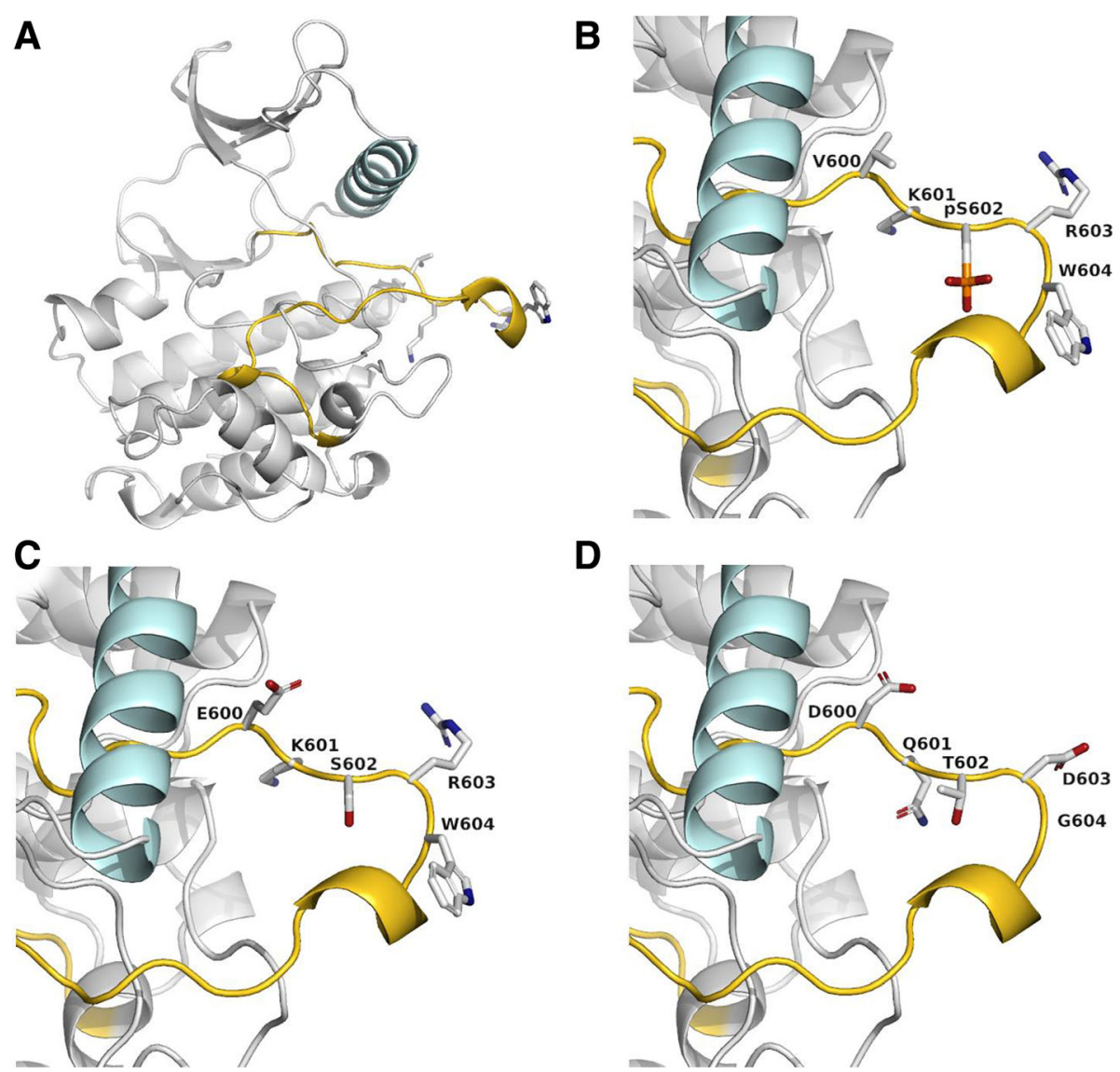

D

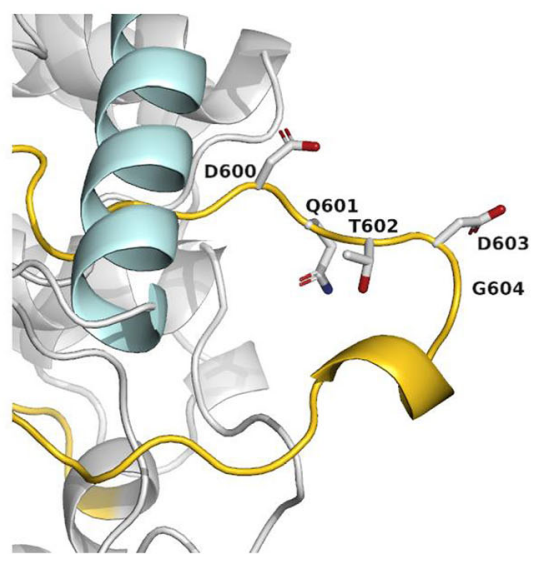

Fig. 3 In Silico Protein Modeling. a Wild-type BRAF kinase domain. Cyan indicates aC helix; gold, activation loop. Residues affected by novel indel are colored according to type of atom. $\mathbf{b}$ Normal activation mechanism of wild-type BRAF protein. c BRAF V600E constitutively active variant. $\mathbf{d}$ Novel BRAF indel with changes to numerous amino acids in the kinase domain activation loop, consistent with a kinase-active conformation

at 8 months postoperatively. The patient is alive with marked decrease in residual tumor and leptomeningeal disease 14 months after the initial surgery (Fig. 1d).

Comprehensive tumor molecular profiling led to the discovery of a novel $B R A F$ alteration, increasing the number of $B R A F$ alterations identified in DIG/ DIA. The oncogenic role of this novel BRAF alteration is supported by the protein modeling and by the observed clinical response to BRAF-MEK inhibitors. This finding suggests that, like other low-grade neuroepithelial tumors $[6,7,11]$, mitogen-activated protein kinase (MAPK) pathway activation may have a potential oncogenic-driver role in a subset of patients with DIG/ DIA. After complete DIG/DIA resection, patients typically have a favorable outcome regardless of the histologic features. Dissemination, as in our patient, is exceedingly rare, and no histologic or molecular parameters are currently predictive of a less favorable outcome [1]. Although additional studies are needed, the responsiveness to BRAF-MEK inhibitors in a DIG with a novel, likely oncogenic $B R A F$ alteration suggests that routine molecular testing for this rare pediatric tumor may be part of a personalized medicine approach, particularly when gross total resection is not achieved and adjuvant therapy is considered.

\section{Additional files}

Additional file 1: Supplementary methods. (DOCX $37 \mathrm{~kb}$ )

Additional file 2: DNA NGS results. (TIF $699 \mathrm{~kb}$ )

Additional file 3: Sanger sequencing results. (TIF $522 \mathrm{~kb}$ )

Additional file 4: RNA sequencing results. (TIF $443 \mathrm{~kb}$ )

Additional file 5: In silico protein modelling. (TIF $690 \mathrm{~kb}$ )

\section{Abbreviations}

DIA: Desmoplastic infantile astrocytoma; DIG: Desmoplastic infantile ganglioglioma; MAPK: Mitogen-activated protein kinase 


\section{Authors' contributions}

$M M B, C K, V L H$ and $C M I$ compiled the clinical and pathological data. MMB, PRB, VLH and CMI compiled the radiologic data. PRB, JRB, CDZ, EGBF, RAJ, AAN, MTZ, RBJ, KCH, BRK and CMI carried out the molecular genetic studies and protein modeling. MMB, PRB and CMI conceived of the study and participated in its design and coordination. All authors read and approved the final manuscript

\section{Ethics approval and consent to participate}

All procedures performed in studies involving human participants were in accordance with the ethical standards of the institutional and/or national research committee and with the 1964 Helsinki declaration and its later amendments or comparable ethical standards. The need for informed consent was waived for this study, which posed minimal risk.

\section{Competing interests}

The authors declare that they have no competing interests.

\section{Publisher's Note}

Springer Nature remains neutral with regard to jurisdictional claims in published maps and institutional affiliations.

\section{Author details}

'Department of Laboratory Medicine and Pathology, Mayo Clinic, 200 First St SW, Rochester, MN 55905, USA. ²Department of Health Sciences Research, Mayo Clinic, Rochester, MN, USA. ${ }^{3}$ Department of Pathology, Dell Children's Medical Center, Austin, TX, USA. ${ }^{4}$ Neuro-Oncology Division, Dell Children's Medical Center, Austin, TX, USA. ${ }^{5}$ Bioinformatics Research and Development Laboratory, Genomics Sciences and Precision Medicine Center, Medical College of Wisconsin, Milwaukee, WI, USA.

Received: 6 September 2018 Accepted: 18 October 2018

\section{Published online: 05 November 2018}

\section{References}

1. Brat DJ, VandenBerg SR, Figarella-Branger D, Reuss DE (2016) Desmoplastic infantile astrocytoma and ganglioglioma. In: Louis DN, Ohgaki H, Wiestler $\mathrm{OD}$, Cavenee WK (eds) WHO classification of tumours of the central nervous system, 4th edn. International Agency for Research on Cancer, Lyon, pp 144-146

2. De Munnynck K, Van Gool S, Van Calenbergh F, Demaerel P, Uyttebroeck A, Buyse G, Sciot R (2002) Desmoplastic infantile ganglioglioma: a potentially malignant tumor? Am J Surg Pathol 26:1515-1522

3. Dougherty MJ, Santi M, Brose MS, Ma C, Resnick AC, Sievert AJ, Storm PB, Biegel JA (2010) Activating mutations in BRAF characterize a spectrum of pediatric low-grade gliomas. Neuro-Oncology 12:621-630. https://doi.org/ 10.1093/neuonc/noq007

4. Gessi M, Zur Muhlen A, Hammes J, Waha A, Denkhaus D, Pietsch T (2013) Genome-wide DNA copy number analysis of desmoplastic infantile astrocytomas and desmoplastic infantile gangliogliomas. J Neuropathol Exp Neurol 72:807-815. https://doi.org/10.1097/NEN.0b013e3182a033a0

5. Greer A, Foreman NK, Donson A, Davies KD, Kleinschmidt-DeMasters BK (2017) Desmoplastic infantile astrocytoma/ganglioglioma with rare BRAF V600D mutation. Pediatr Blood Cancer 64. https://doi.org/10.1002/pbc.26350

6. Huse JT, Snuderl M, Jones DT, Brathwaite CD, Altman N, Lavi E, Saffery R, Sexton-Oates A, Blumcke I, Capper D, Karajannis MA, Benayed R, Chavez L, Thomas C, Serrano J, Borsu L, Ladanyi M, Rosenblum MK (2017) Polymorphous low-grade neuroepithelial tumor of the young (PLNTY): an epileptogenic neoplasm with oligodendroglioma-like components, aberrant CD34 expression, and genetic alterations involving the MAP kinase pathway. Acta Neuropathol 133:417-429. https://doi.org/10.1007/s00401016-1639-9

7. Jeuken JW, Wesseling P (2010) MAPK pathway activation through BRAF gene fusion in pilocytic astrocytomas; a novel oncogenic fusion gene with diagnostic, prognostic, and therapeutic potential. J Pathol 222:324-328. https://doi.org/10.1002/path.2780

8. Koelsche C, Sahm F, Paulus W, Mittelbronn M, Giangaspero F, Antonelli M, Meyer J, Lasitschka F, von Deimling A, Reuss D (2014) BRAF V600E expression and distribution in desmoplastic infantile astrocytoma/ ganglioglioma. Neuropathol Appl Neurobiol 40:337-344. https://doi.org/10 1111/nan.12072
9. Milanaccio C, Nozza P, Ravegnani M, Rossi A, Raso A, Gambini C, Garre ML, Pietsch T (2005) Cervico-medullary desmoplastic infantile ganglioglioma: an unusual case with diffuse leptomeningeal dissemination at diagnosis. Pediatr Blood Cancer 45:986-990. https://doi.org/10.1002/pbc.20325

10. Prabowo AS, lyer AM, Veersema TJ, Anink JJ, Schouten-van Meeteren AY, Spliet WG, van Rijen PC, Ferrier CH, Capper D, Thom M, Aronica E (2014) BRAF V600E mutation is associated with mTOR signaling activation in glioneuronal tumors. Brain Pathol 24:52-66. https://doi. org/10.1111/bpa.12081

11. Tatevossian RG, Lawson AR, Forshew T, Hindley GF, Ellison DW, Sheer D (2010) MAPK pathway activation and the origins of pediatric low-grade astrocytomas. J Cell Physiol 222:509-514. https://doi.org/10.1002/jcp.21978

12. Zhang J, Wu G, Miller CP, Tatevossian RG, Dalton JD, Tang B, Orisme W, Punchihewa C, Parker M, Qaddoumi I, Boop FA, Lu C, Kandoth C, Ding L, Lee R, Huether R, Chen X, Hedlund E, Nagahawatte P, Rusch M, Boggs K, Cheng J, Becksfort J, Ma J, Song G, Li Y, Wei L, Wang J, Shurtleff S, Easton J, Zhao D, Fulton RS, Fulton LL, Dooling DJ, Vadodaria B, Mulder HL, Tang C, Ochoa K, Mullighan CG, Gajjar A, Kriwacki R, Sheer D, Gilbertson RJ, Mardis ER, Wilson RK, Downing JR, Baker SJ, Ellison DW, St. Jude Children's Research Hospital-Washington University Pediatric Cancer Genome Project (2013) Whole-genome sequencing identifies genetic alterations in pediatric lowgrade gliomas. Nat Genet 45:602-612. https://doi.org/10.1038/ng.2611
Ready to submit your research? Choose BMC and benefit from:

- fast, convenient online submission

- thorough peer review by experienced researchers in your field

- rapid publication on acceptance

- support for research data, including large and complex data types

- gold Open Access which fosters wider collaboration and increased citations

- maximum visibility for your research: over $100 \mathrm{M}$ website views per year

At $\mathrm{BMC}$, research is always in progress.

Learn more biomedcentral.com/submissions 